\title{
EVALUASI MIKROSTRUKTUR KULIT TELUR ITIK PASCA FORMULASI KHITOSAN-ASAP CAIR SELAMA PENGASINAN
}

\author{
MIWADA, I N. S., M. HARTAWAN, DAN I K. SUKADA \\ Fakultas Peternakan Universitas Udayana \\ e-mail: nymsumerta@yahoo.co.id
}

\begin{abstract}
ABSTRAK
Tujuan penelitian ini adalah untuk menganalisis kemampuan formula khitosan-asap cair dalam membantu inovasi waktu pemeraman dengan penetrasinya melewati pori-pori kulit telur selama pengasinan. Metode penelitian menggunakan rancangan acak lengkap (RAL) dengan perlakukan lama pemeraman $(5 ; 10 ; 15$ dan 20 hari). Formula khitosan-asap cair dengan konsentrasi $20 \mathrm{~g} / \mathrm{l}$ dan 3\% digunakan pada penelitian ini. Hasil penelitian menunjukkan bahwa pemeraman hingga 15 hari memberikan nilai skor tertinggi $(\mathrm{P}<0,05)$ dengan kriteria suka. Kualitas kimia dengan lama pemeraman memberikan hasil yang berbeda nyata $(\mathrm{P}<0,05)$ baik ditinjau dari indikator nilai $\mathrm{pH}$, protein, kandungan fenol dan total asam. Hasil pengamatan SEM (Scanning Electron Microscope) menunjukkan mikrostruktur kulit telur yang lebih terbuka dengan adanya formulasi khitosan-asap cair. Kesimpulan penelitian ini bahwa formulasi khitosan dengan konsentrasi $20 \mathrm{~g} / \mathrm{l}$ dan asap cair dengan konsentrasi $3 \%$ dapat dilakukan dengan efektif pada pemeraman selama 15 hari.
\end{abstract}

Kata kunci: khitosan. asap cair, telur asin, mikrostruktur kulit telur

\section{EVALUATION OF EGG SHELL MICROSTRUCTURE PASCA FORMULATION OF KHITOSAN LIQUID SMOKE IN POST TIME SALTING}

\begin{abstract}
This study aims at analyzing the ability of chitosan-formula liquid smoke to make innovation of curing times with penetration through the pores of duckling egg shells on the process of salting. A completely randomized design (CRD) was used with long curing treatment in 5, 10, 15, and 20 days. Besides, formula chitosan-liquid smoke with $20 \mathrm{~g} / \mathrm{l}$ and $3 \%$ concentration were used in this experiment. The results showed that the curing of time up to 15 days gave the highest score $(\mathrm{P}<0.05)$ with good criteria. The quality of chemical in a long curing times gave significant differences $(\mathrm{P}<0.05)$ from indicators as of $\mathrm{pH}$ value, protein, and content of total phenol, and acids. The result of SEM (Scanning Electron Microscope) showed that formulation of chitosan-liquid smoke could give effect to a relatively open eggshells microstructure. It can be concluded that chitosan formulation with $20 \mathrm{~g} / \mathrm{l}$ concentration and $3 \%$ of liquid smoke concentration can be effective at 15 days curing time.
\end{abstract}

Keywords: chitosan. liquid smoke, salted egg, eggshell microstructure

\section{PENDAHULUAN}

Telur, merupakan produk hasil ternak dan selama ini kebutuhannya sangat banyak sebagai sumber bahan pangan hewani bernilai fungsional. Selama ini, waktu pengolahan merupakan salah satu kendala dalam diversifikasi olahan telur utuh. Hal ini disebabkan karena secara fisik, telur utuh memiliki kulit yang secara tidak langsung menjadi pennyebab lamanya proses pengolahan telur utuh. Seperti diketahui, pengolahan telur asin membutuhkan waktu lebih dari satu minggu agar proses pengasinannya menjadi optimal. Pengolahan telur utuh secara konvensional, proses penetrasi bahan ke dalam telur hanya mengandalkan pori-pori kulit secara alami. Meskipun jumlah poripori kulit telur tersebut cukup banyak (disebutkan oleh Brown (2000) yakni lebih dari 7000-8000 pori yang biasanya digunakan untuk pertukaran gas dan besar lubang porinya berukuran 0,01-0,07 $\mathrm{mm}$ yang tersebar di seluruh permukaan kulit telur.) namun belum mampu membantu percepatan pengolahan telur utuh tersebut.

Penelitian untuk membuka pori kulit telur dan sekaligus meningkatkan sorpsi (penetrasi) asap cair ke dalam telur perlu dilakukan, sebagai suatu alternatif inovasi dalam upaya diversifikasi produk olahan telur asap dengan tanpa merusak kulit telur. Proses 
ini diduga dapat dilakukan dengan terlebih dahulu dilakukan perendaman menggunakan larutan khitosan. Dasar pemikirannya, dari beberapa penelitian diduga aplikasi khitosan mampu memberikan terobosan sebagai pembuka pori dan meningkatkan absorpsi suatu bahan tertentu ke dalam material tertentu serta sekaligus berfungsi sebagai pengawet. Riset pembuka pori dari aplikasi khitosan telah dilakukan pada kain kapas. Hal itu dilaporkan oleh Noerati (2005) yang menyebutkan bahwa perendaman kain kapas dalam larutan khitosan dapat meningkatkan penyerapan (absorpsi) kain terhadap asam sitrat. Ini diduga bahwa khitosan dapat meningkatkan/membuka ukuran poripori kain tersebut sehingga asam sitrat lebih leluasa dapat memasuki pori. Trimulyadi et al.(2005) juga telah meneliti mengenai pemanfaatan khitosan teriradiasi sebagai bahan penginduksi (peningkatan absorpsi) terhadap cabe sehingga pertambahan tingginya menjadi meningkat. Tujuan penelitian ini adalah untuk menganalisis kemampuan formula khitosan-asap cair dalam membantu inovasi waktu pemeraman dengan penetrasinya melewati pori-pori kulit telur selama pengasinan.

\section{MATERI DAN METODE}

\section{Materi}

Bahan dasar penelitian ini adalah telur itik, khitosan, asap cair dari tempurung kelapa dan bahan-bahan ekstrak bawang merah, putih dan kunyit. Bahan-bahan pendukung lainya adalah meliputi natrium hidroksida $(\mathrm{NaOH})$, asam klorida $(\mathrm{HCl})$, aseton, natrium hipoklorit (NaOCl), buffer $\mathrm{pH} 4, \mathrm{OO}$, buffer $\mathrm{pH}$ 7,00, buffer $\mathrm{pH}$ 9,00, phenolphtalein (pp), aquades, air bebas ion (deionized water), kertas saring biasa, dan kertas saring Whatman 42. Alat-alat yang digunakan antara lain: kuali, sendok, kompor, peralatan gelas, thermometer, desikator, oven, water bath, timbangan analitik, panci aluminium, ember plastik, kompor, dan alat instrumen meliputi Scaning Elektron Microscope (SEM), dan pH meter.

\section{Preparasi sampel}

Persiapan awal yang dilakukan adalah dengan menyiapkan dan membersihkan terlebih dahulu alatalat yang digunakan, seperti kuali, alat gelas dan lainlain. Setelah itu, memilih dan menyeleksi telur itik yang meliputi kesegarannya, kulitnya tidak pecah atau retak, dan isi telur tidak ada noda. Setelah itu, mencuci cangkang telur dari kotoran yang melekat dan kemudian dilap agar cepat kering. Dipilih telur itik sebanyak 200 butir dengan berat mendekati berat rata-rata kelompok dan masing-masing diacak serta dibagi sesuai jumlah perlakuan.

\section{Tahapan Penelitian}

Formulasi optimum khitosan-asap cair pada tahap pertama penelitian ini yakni $20 \mathrm{~g} / \mathrm{l}$ dan konsentrasi asap cair 3\% (Miwada et al., 2016) dan kemudian dilanjutkan aplikasinya dengan penetuan lama pemeraman ( L1 = 5 hari; L2 $=10$ hari; L3 $=15$ hari dan L4 $=20$ hari). Pasca preparasi sampel tersebut dilanjutkan dengan pembuatan telur asin dengan metode konvensional. Setelah matang, disiapkan adonan pelapis (campuran tepung tapioka, garam, dan air) dan satu persatu telur diberi adonan pelapis. Kemudian, telur dikeringkan dengan cara menjemur langsung di bawah sinar matahari selama 10 menit hingga lapisan mengering dan dilanjutkan dengan uji kualitas.

\section{Variabel yang diamati}

Variabel yang diamati meliputi struktur mikroskopis kulit telur, pH, protein, total asam, kadar fenol dan uji sifat-sifat sensoris meliputi warna; citarasa dan aroma.

\section{Analisis Data}

Rancangan risetmenggunakan rancangan acak lengkap (RAL) yakni lama pemeraman $(5 ; 10 ; 15$ dan 20 hari). Perlakuan masing-masing dilakukan pengulangan sebanyak 3 kali. Data yang diperoleh dianalisis secara sidik ragam dengan bantuan program statistik SPSS Versi 20,0. Perlakuan yang menunjukkan pengaruh yang nyata, selanjutnya dilakukan uji beda nyata dengan Duncan'S Multiple Range Test (DMRT) pada taraf 5\% (Steel dan Torrie, 1991).

\section{HASIL DAN PEMBAHASAN}

Hasil analisis statistik pada Tabel 1, menunjukkan bahwa peningkatan masa pemeraman dalam pengasinan telur itik dengan formulasi khitosan-asap cair memberikan respon panelis yang berbeda nyata $(\mathrm{P}<0,05)$. Fungsi formulasi khitosan-asap cair telah membantu peningkatan kesukaan terhadap warna, citarasa dan aroma dari telur asin asap dengan waktu pemeraman yang lebih singkat. Waktu pemeraman 15 hari memberikan nilai kesukaan tertinggi. Hal ini didukung dengan hasil kajian dengan SEM (Scanning Elektron Microscope) pada Gambar 1, bahwa fungsi formulasi khitosan-asap cair pada kulit telur dengan pembesaran 6000 kali terlihat lebih memberi ruang

Tabel 1. Respon panelis terhadap telur asin asap selama pemeraman

\begin{tabular}{lcccc}
\hline \multirow{2}{*}{ Variabel } & \multicolumn{4}{c}{ Perlakuan Pemeraman } \\
\cline { 2 - 5 } & $\mathrm{L} 1$ & $\mathrm{~L} 2$ & $\mathrm{~L} 3$ & $\mathrm{~L} 4$ \\
\hline Warna & $3,53 \pm 0,05^{\mathrm{a}}$ & $3,67 \pm 0,03^{\mathrm{b}}$ & $4,27 \pm 0,08^{\mathrm{c}}$ & $3,73 \pm 0,06^{\mathrm{b}}$ \\
Citarasa & $3,07 \pm 0,08^{\mathrm{a}}$ & $3,87 \pm 0,17^{\mathrm{b}}$ & $4,06 \pm 0,12^{\mathrm{b}}$ & $3,93 \pm 0,06^{\mathrm{b}}$ \\
Aroma & $3,20 \pm 0,03^{\mathrm{a}}$ & $3,27 \pm 0,03^{\mathrm{a}}$ & $4,13 \pm 0,08^{\mathrm{c}}$ & $4,00 \pm 0,09^{\mathrm{b}}$ \\
\hline
\end{tabular}


Tabel 2. Rata-rata kualitas kuantitatif fisik telur asin asap segar selama pemeraman

\begin{tabular}{lcccc}
\hline \multirow{2}{*}{ Variabel } & \multicolumn{4}{c}{ Perlakuan Pemeraman } \\
\cline { 2 - 5 } & $\mathrm{L} 1$ & $\mathrm{~L} 2$ & $\mathrm{~L} 3$ & $\mathrm{~L}$ \\
\hline Nilai pH & $6,74 \pm 0,05^{\mathrm{b}}$ & $6,29 \pm 0,17^{\mathrm{a}}$ & $6,88 \pm 0,23^{\mathrm{b}}$ & $6,49 \pm 0,09^{\mathrm{a}}$ \\
Protein (\% bb) & $12,78 \pm 0,08^{\mathrm{a}}$ & $14,88 \pm 0,45^{\mathrm{b}}$ & $15,06 \pm 0,06^{\mathrm{b}}$ & $16,82 \pm 0,08^{\mathrm{c}}$ \\
Fenol (mg/100gr GAE) & $44,44 \pm 0,57^{\mathrm{d}}$ & $36,23 \pm 0,16^{\mathrm{c}}$ & $27,42 \pm 0,35^{\mathrm{b}}$ & $20,70 \pm 0,12^{\mathrm{a}}$ \\
Total Asam (\%) & $0,46 \pm 0,06^{\mathrm{b}}$ & $0,28 \pm 0,01^{\mathrm{a}}$ & $0,30 \pm 0,01^{\mathrm{a}}$ & $0,31 \pm 0,01^{\mathrm{a}}$ \\
\hline
\end{tabular}

terbukanya pori-pori kulit telur paling tinggi pada pemeraman 10-15 hari. Peningkatan waktu pemeraman menyebabkan formula itu menjadi tidak maksimal dalam membantu percepatan waktu pengasinan.

Sementara hasil analisis statistik pada Tabel 2, menunjukkan bahwa peningkatan waktu pemeraman berpengaruh nyata $(\mathrm{P}<0,05)$ terhadap nilai $\mathrm{pH}$. Peningkatan waktu pemeraman dalam formulasi khitosan-asap cair untuk pengasinan telur asin asap, secara kualitas kimia memberikan pengaruh yang nyata

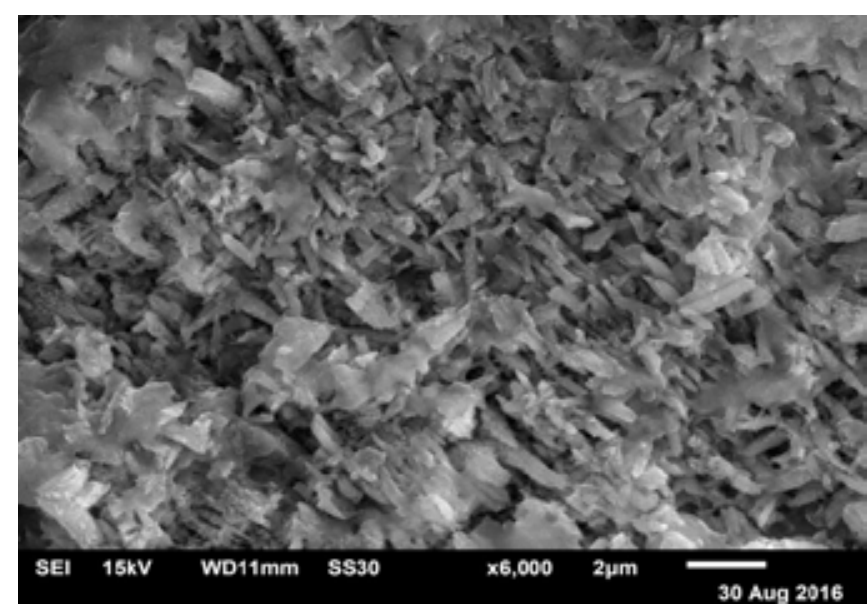

Gambar 1. Mikrostruktur Kulit Telur Asin Dalam Formulasi Khitosan-Asap Cair Selama 5 Hari

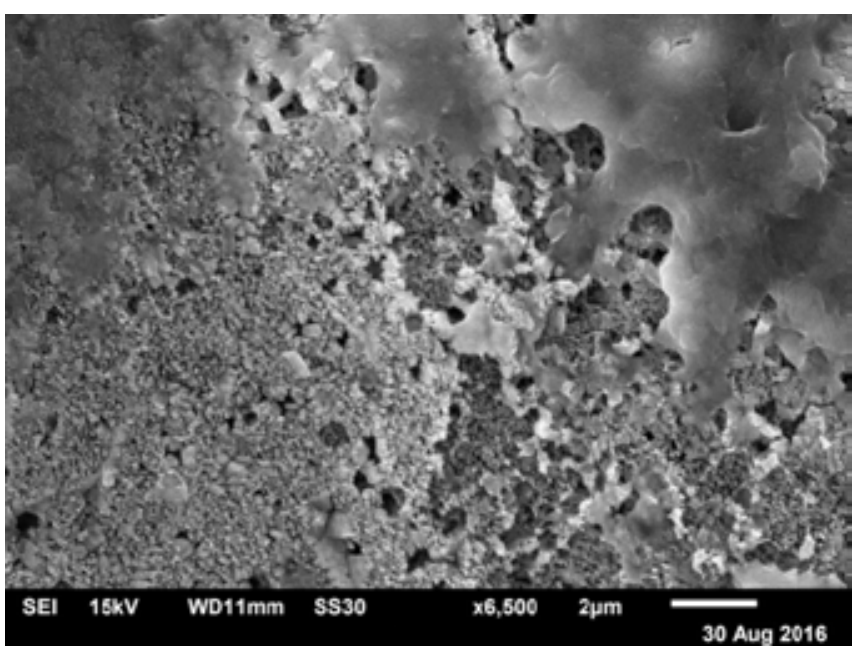

Gambar 3. Mikrostruktur Kulit Telur Asin Dalam Formulasi Khitosan-Asap Cair Selama 15 Hari
$(\mathrm{P}<0,05)$ terhadap kualitas telur asin asap. Peningkatan waktu pemeraman meningkatkan kandungan protein telur hal ini diduga karena penetrasi pembuka pori dari khitosan dengan gugus fungsinya yang sangat reaktif akhirnya berinteraksi dengan gugus amino pada telur yang memberikan kontribusi kandungan protein yang tinggi. Peningkatan waktu pemeraman dalam pengasinan telur menurunkan kandungan fenol $(\mathrm{P}<0,05) . \mathrm{Hal}$ ini diduga disebabkan karena karakter larutan khitosan-asap cair itu mengalami penggumpalan

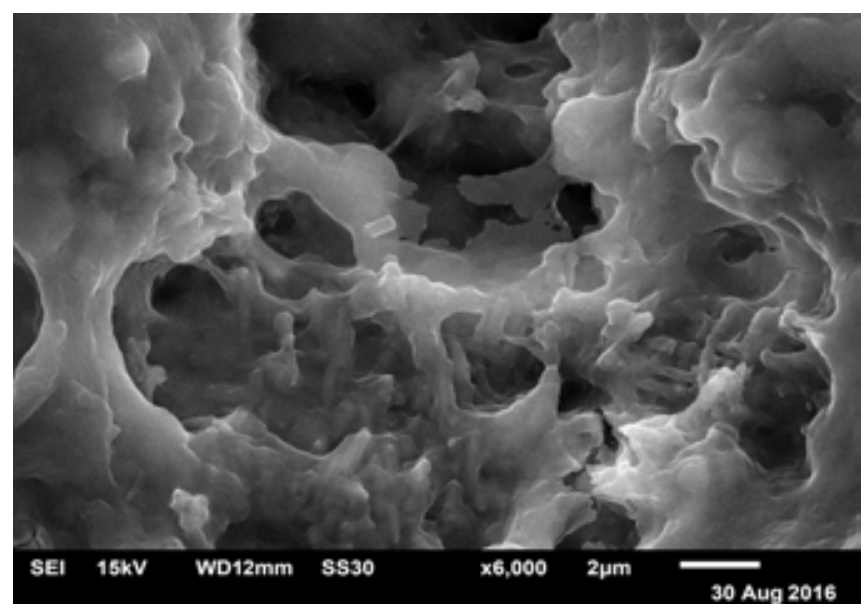

Gambar 2. Mikrostruktur Kulit Telur Asin Dalam Formulasi Khitosan-Asap Cair Selama 10 Hari

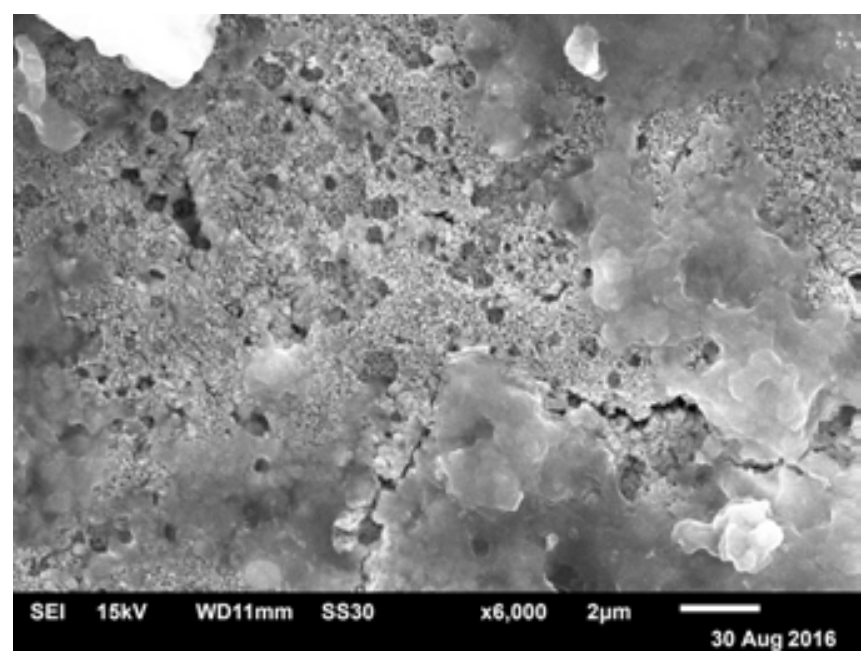

Gambar 4. Mikrostruktur Kulit Telur Asin Dalam Formulasi Khitosan-Asap Cair Selama 20 Hari 
seiring dengan semakin lamanya pemeraman dan hal ini dampaknya bias diamati pada pengamatan SEM yakni terlihat permukaan struktur kulit formula khitosanasap cair menumpuk. Penumpukan ini diduga menjadi penyebab semakin rendahnya kandungan fenol pada telur.

\section{SIMPULAN}

Hasil penelitian bahwa formulasi khitosan dengan konsentrasi $20 \mathrm{~g} /$ dan konsentrasi asap cair 3\% menunjukkan hasil terbaik dengan indicator kajian organoleptik (warna, aroma dan citarasa) maupun dari hasil pengukuran secara kuantitatif terhadap warna telur. Hasil kajian pengamatan SEM menunjukkan bahwa formulasi khitosan-asap cair dengan lama pemeraman 15 hari menunjukkan hasil terbaik.

\section{UCAPAN TERIMA KASIH}

Pada kesempatan ini, tim peneliti mengucapkan banyak terimakasih pada Dekan Fakultas Peternakan Universitas Udayana melalui surat perjanjian kerja dalam rangka pelaksanaan penelitian dana PNBP nomor :485A/UN14.125/PNL/2O16

\section{DAFTAR PUSTAKA}

Brown, A. 2000. Understanding Food Principles and Preparation. University of Hawaii. Wardsworth.

Darmadji, P. 2009. Teknologi Asap Cair dan Aplikasinya pada Pangan dan Hasil Pertanian. Universitas Gadjah Mada. Yogyakarta.

Miwada, I N. S., M. Hartawan, dan I K. Sukada. 2016. Kajian Formulasi Khitosan-Asap Cair dan Pengaruhnya terhadap Kualitas Telur Asin Asap. Laporan Penelitian HUPS.

Noerati, 2005. Pengaruh Pengerjaan Kitosan dan Asam Sitrat pada Kain Kapas terhadap Sifat Fisik Kain. JSChem ITB-UKM VI-2005.

Steel, R. G. D. dan J. H. Torrie. 1991. Principle and Procedure of Statistic. Mc.Graw Hill. Book Company Inc. New York.

Trimulyadi, G. R., Kadariah, Sunarni, A., Marlianti, I., dan Iramani, D. 2005. Pengaruh Dosis Iradiasi pada Khitosan Sebagai Bahan Penginduksi Pertumbuhan Tanaman Cabe (Capcinum annum). JSChem ITBUKM VI-2005. 